\title{
Characterising the UK Terrorist Threat: The Problem with Non- Violent Ideology as a Focus for Counter-Terrorism and Terrorism as the product of 'Vulnerability'
}

\author{
by Anthony Richards
}

\section{Introduction}

T his article investigates two particular aspects as to how the terrorist threat in the UK has been characterised, arguing that they both challenge conventional academic wisdom as to how terrorism should be conceptualised. While such conventional wisdom should always be open to challenge, and policymaking perspectives are different to those of academics, these two particular aspects as to how the terrorist threat has been perceived in the UK merit scrutiny, especially as counter-terrorism strategies have been premised on them. They are: i) the contemporary and explicit concern with 'extremist' but non-violent ideas that are said to be 'conducive' to terrorism as a focus for a counter-terrorism response and ii) the notion that terrorism has increasingly been seen as the product of 'vulnerability'. The first, and the main focus of this article, appears to challenge the widely held view within terrorism studies that, when defining terrorism, reference to the cause or the perpetrator is unhelpful because terrorism should first and foremost (and more objectively) be seen as a particular method of violence that has been used by a wide variety of actors, regardless of the ideology or the belief systems of its perpetrators. The second aspect - the impetus towards viewing terrorism as the product of vulnerability or individual fallibility - arguably implies a diminished capacity for rational behaviour, which challenges a further commonly held view within terrorism studies: that terrorism entails the use of calculated and rational acts of violence.

\section{The 2011 versions of Contest and Prevent}

In June 2011 the British government's updated Prevent strategy was published and was followed a month later by the third version of its Contest strategy. Arguably, the most interesting and controversial theme running through the two documents is the increasing emphasis on ideology as a focus for a counter-terrorism response. In particular, counter-terrorism in the UK now appears to be concerned with 'extremist (and non-violent) ideas that are also part of a terrorist ideology' and that are 'conducive' to terrorism. In the context of a burgeoning policy interest with the concept of 'radicalisation' in recent years and its rather indeterminate scope (when it hadn't always been clear as to what precisely the remit of counter-terrorism had been), these new documents in 2011 represented something of a step change in that they more explicitly focus on ideology, and even non-violent ideology, as an important part of the remit of counter-terrorism.

Early in the Contest document it states that 'Greater effort will be focused on responding to the ideological challenge and the threat from those who promote it'[1] and goes on to argue that: 


\section{Journal of Terrorism Research}

'We believe that Prevent work to date has not clearly recognised the way in which some terrorist ideologies draw on and make use of extremist ideas which are espoused and circulated by apparently non-violent organisations, very often operating within the law... preventing radicalisation must mean challenging extremist ideas that are conducive to terrorism and also part of a terrorist narrative.' [2]

The document makes it clear that radical action is required against those who are not just terrorists but who may have non-violent but 'extremist' views. Extremism is defined in the Prevent document as 'vocal or active opposition to fundamental British values, including democracy, the rule of law, individual liberty and mutual respect and tolerance of different faiths and beliefs.'[3] A clear distinction is made between terrorism and (non-violent) extremism but both are now, it seems, to be the focus of a counter-terrorism strategy: 'where people seek to enter this country from overseas to engage in activity in support of extremist as well as terrorist groups we will also use the Home Secretary's powers to exclude them.' [4] The document justifies this strategy by arguing that:

'The focus of Prevent to date has been on violent extremism and terrorism. It has not explicitly considered non violent extremism. However a significant percentage of people who engage in terrorism have previously been associated with extremist groups; some terrorist organisations - of all kinds - also share and make use of ideas which are popularised by extremists. In some cases extremist groups carefully operate within our laws, deliberately avoiding open support for violence but knowingly creating an environment in which people can be drawn into terrorism itself. We believe that Prevent work therefore necessarily has to deal with some aspects of extremism and this is clearly reflected in our new strategy. We emphasise here that we have no intention of labelling particular faith groups (and orthodox faith in particular) as inherently extremist. That is neither our view nor our purpose.' [5]

The revised Prevent document at the outset announces the intention to 'respond to the ideological challenge of terrorism and the threat from those who promote it. In doing so, we must be clear: the ideology of extremism and terrorism is the problem; legitimate religious belief emphatically is not', before going on to state that 'preventing terrorism will mean challenging extremist (and nonviolent) ideas that are also part of a terrorist ideology.'[6] It is the notion of tackling 'non-violent' ideology as part of a counter-terrorism response that seems to be most controversial about the new strategy. It is justified on the grounds that:

'Some politically extreme organisations routinely claim that: the West is perpetually at war with Islam; there can be no legitimate interaction between Muslims and non-Muslims in this country or elsewhere; and that Muslims living here cannot legitimately and or effectively participate in our democratic society. Islamist extremists can specifically attack 


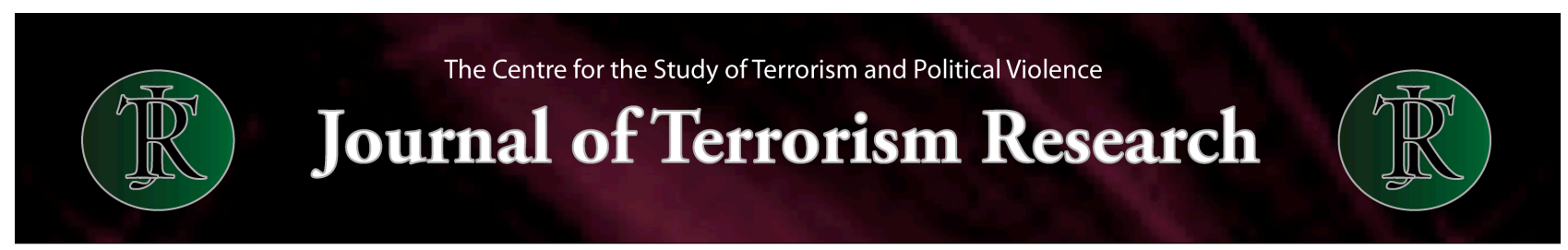

the principles of participation and cohesion, rejection of which we judge to be associated with an increased willingness to use violence ... Islamist extremists can purport to identify problems to which terrorist organisations then claim to have a solution.' [7]

Prevent will, therefore, 'mean intervening to try to stop people moving from extremist groups or extremism into terrorist-related activity.' [8] It is this potential conduit between non-violent extremism and terrorism that the government is seeking to address:

'Some people who become members of terrorist groups have previously been members of extremist organisations and have been radicalised by them. Others (though not all) pass through an extremist phase ... Preventing people becoming terrorists will require a challenge to extremist ideas where they are used to legitimise terrorism and are shared by terrorist groups. It will also require intervention to stop people beginning to move away from extremist but legal groups into proscribed illegal terrorist organisations.' [9]

\section{The context of 'radicalisation' as a focus of C-T}

The increasing emphasis on non-violent ideology has taken place in the context of a burgeoning policy interest in the phenomenon of 'radicalisation' in the past seven or eight years. This wider concern with radicalisation as a focus of the UK's counter-terrorism response facilitated the expansion of the remit of c-t beyond countering terrorism and into other policy areas such as those to do with societal cohesion and integration, although the latest Prevent strategy distances itself from the integration agenda. Yet, because there has been little consensus as to what is meant by radicalisation, or who the 'radicalised' refers to, the remit of counter-terrorism or 'counterradicalisation' also lacked clarity - evident in a 'Prevent' strand of Contest that, prior to 2011, 'confusingly oscillated between tackling violent extremism in particular to promoting community cohesion and 'shared values' more broadly'.[10]

Despite the then broader 'societal' and ideological objectives to do with shared values within c-t strategy, the 2009 version of Contest restricted its definition of radicalisation to: 'the process by which people come to support violent extremism and, in some cases, join terrorist groups'.[11] This definition inextricably links radicalisation to violence rather than to any non-violent goals. It is perhaps even more surprising, then, given its more explicit focus on non-violent ideology and (nonviolent) 'extremism', that the latest version of Contest also confines its definition of radicalisation to 'the process by which people come to support, and in some cases to participate in terrorism'.[12] This doesn't appear to tally with the implied (non-violent) meaning of radicalisation in the same document when it proposed that 'preventing radicalisation must mean challenging extremist ideas'. [13]

It seems reasonable to suggest, however, that, notwithstanding these narrow definitions, there are in fact both violent and non-violent forms of radicalisation. Demos concurred that 'the last decade in particular has also seen a growth in many types of what it called non-violent radicalisation' [italics added] and argued that 'a successful counter-terrorism strategy must be based on a clear understanding of these distinct forms of radicalisation'.[14] It also seems clear that the concern with radicalisation as a focus for a counter-terrorism response has expanded the remit of counter- 


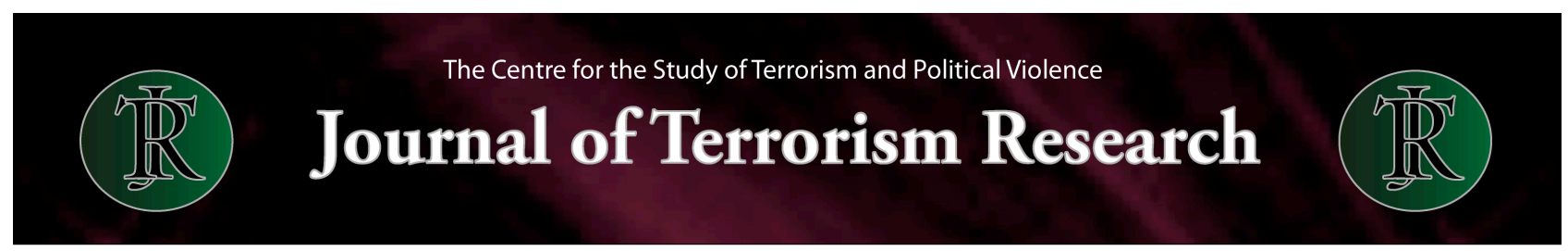

terrorism to tackling (non democratic) ideas as well as terrorism, and this has now been made more explicit in the updated versions of Contest and Prevent in 2011.

\section{Terrorism as a particular method of violence}

The characterisation of the terrorist threat in the UK as being something inherently linked to certain non-violent ideologies challenges conventional wisdom within terrorism studies on how terrorism is conceptualised - that it is best understood as a particular method of violence and definitions that make reference to the perpetrator or to the particular cause (beyond being political) are unhelpful. As Leonard Weinberg so rightly observed the notion of 'one man's terrorist is another man's freedom fighter' is confusing the goal with the activity.[15] So too, therefore, does the view (apparently articulated by the UN Secretary-General in March 1987 in relation to the Palestinian Liberation Organization and the South West Africa People's Organization) that 'sometimes it is difficult to tell where terrorism ends and the struggle for self-determination begins.' [16] It is also why many observers miss the point when they pose such questions as: 'where to draw the line between the quest for nationalist identity and an act of terrorism ...?'[17] or when Yasir Arafat declared that:

\section{'The difference between the revolutionary and the terrorist lies in the reason for which} each fights. For whoever stands by a just cause and fights for the freedom and liberation of his land from the invaders, the settlers and the colonialists, cannot possibly be called a terrorist ....'·[18]

The difference between the terrorist and the non terrorist does not lie in the reason for which one fights, as Arafat proclaimed. Otherwise we are conceding that terrorism really is 'violence that we don't like' (or whose cause we disagree with) and that there is in fact nothing qualitatively distinctive about terrorism compared with other forms of political violence. When faced with terrorist attacks, such as those of $9 / 11,7 / 7$, or Madrid, this is presumably a position that policymakers do not countenance.

Terrorism is a distinctive phenomenon that is not inherent to any particular non violent ideology. It has been used as a method in pursuit of a wide range of ideologies most of which are not inherently violent. There are, however, some ideologies where the use of violence is integral to the ideology itself -such as fascism, as in the cases of Hitler's Germany and Mussolini's Italy. This particular ideology has underpinned some of the most brutal campaigns of 'state terror'. The violence that may be integral to the ideology, however, is not necessarily terrorist violence. For example, in the context of sub-state neo-fascist groups, terrorism may be the particular method of violence used as the means to an end, even if that end entails the continued use of violence through other forms such as more widespread 'state terror' or 'political terror' as distinct from terrorism. In other words even general ideologies of violence are not inherently 'terrorist', though they may be more 'conducive' to terrorism.

There may also be ideologies that have been interpreted, adapted or distorted to explicitly justify the use of terrorism and where terrorism may then become ideologically embedded. In this sense one might indeed call them 'terrorist ideologies' where the use of terrorism is intrinsic to the doctrine. It could be argued that this is the case with Al Qaeda and the notion of terrorism and political violence as a religious duty, or indeed with the tradition of 'physical force' Irish republicanism - for example Patrick Pearse's proclamations of the notion of self-sacrificial acts as being a compelling symbol of 


\section{Journal of Terrorism Research}

republican ideology - or left wing dogmas that aim to rouse the consciousness of the proletariat through the violent acts of the self-appointed vanguards of the anticipated communist revolution. But there are, of course, many nationalist, religious, left wing, right wing, and single issue (antiabortion, animal rights, environmental) ideologies that are not inherently violent though terrorism has often been employed in their name. Terrorism is not something intrinsic to any particular non violent ideology but is a method of violence that has at some time or other been perpetrated in the cause of doctrines within all of these categories.

While one concedes that violence is intrinsic to some ideologies, and that, further, terrorist violence itself may be embedded in some doctrines, and that therefore one could indeed argue that some ideologies may be more 'conducive' to terrorism than others, the idea of a non-violent ideology as being conducive to terrorism, and therefore of concern to counter-terrorism, is more difficult to grasp. To reiterate, 'terrorism is a method of combat'[19] or as Martha Crenshaw, a respected scholar in the field, put it: 'The method, not the identity or ideology of the user, determines whether or not an action can be defined as terrorism.'[20]

Terrorism has been used by a wide range of actors (states, guerrilla groups, terrorist organisations etc.) in pursuit of an even wider range of ideologies (both violent and non-violent) and, when theorising terrorism, is therefore best seen as a particular method rather than inherent to any particular actor or ideology (and certainly not to any non-violent ideology). As offensive as we may find some ideologies, labelling particular non-violent causes or doctrines as conducive to terrorism, seems to be deflecting us away from the essence of terrorism as a method and, in doing so, to be broadening the remit of counter-terrorism beyond it. Pillar perceptively argues that terrorism is something that 'people (or groups, or states) $d o$, rather than who they are or what they are trying to achieve' (author's italics).[21] Terrorism, as a method, should be 'defined by the nature of the act, not by the identity of the perpetrators or the nature of their cause.' [22]

Returning to the Contest and Prevent strategies it is 'extremist ideology' that is seen as conducive to terrorism and, to reiterate, extremism is defined as:

'vocal or active opposition to fundamental British values, including democracy, the rule of

law, individual liberty and mutual respect and tolerance of different faiths and beliefs.'

We can then perhaps infer from this that any undemocratic ideology or any ideology that contravenes British values can potentially be a part of a 'terrorist ideology', even if it is non-violent. To what extent, therefore, for example, are communist parties in democratic societies culpable for the activities of terrorist organisations who have the same ideological outlook but who use different methods? And on contemporary radical but non-violent views, Demos makes the critical point that 'Assuming that radical views constitute the base of the terrorist pyramid can allow for counterradicalisation strategies against large numbers of people who object entirely to al Qaeda's methods' (italics added). [23]

The new version of Contest has set out to ensure that 'there is more effective challenge to those extremists whose views are shared by terrorist organisations and used by terrorists to legitimise violence'.[24] This would, of course, have been treated with consternation during the 'Troubles' of Northern Ireland if this was applied to the non-violent Social Democratic and Labour Party who shared a similar (nationalist) ideology with the Irish Republican Army, or indeed to the unionist parties because they shared an opposing nationalist ideology with loyalist terrorist organisations. The difference is that the British government had no particular aversion to either of these nationalist ideologies but they did object to the methods used by the IRA and the loyalist terrorist 


\section{Journal of Terrorism Research}

organisations. In the face of the contemporary threat the British government is concerned with ideology, aswell as the methods used to pursue it. It is, however, debateable as the extent to which non-violent and legal ideological challenges to British democracy should be the concern of a counter-terrorism strategy in addition to any (terrorist) methods used to support them.

What, then, are the implications of characterising the terrorist threat in this way for counterterrorism? The first logical outcome is that 'intervention providers' tasked with preventing individuals becoming terrorists are not permitted to share the same ideological outlook as them: 'intervention providers must not have extremist beliefs' and yet 'they must have credibility' and be 'able to reach and relate to' them.[25] While there is no evidence on this available to the author it does prompt the question as to how effective 'non-extremist' interveners are in comparison to 'extremist' ones, and to what extent, if at all, this exclusion of non-violent extremist interveners helps or hinders what should surely be the primary goal of counter-terrorism - preventing acts of terrorism.

While it is important to acknowledge the government's concern that a 'significant percentage of people who engage in terrorism have previously been associated with [non-violent] extremist groups', one has to question whether any non-violent ideology itself can be culpable for this, rather than those who would urge the adoption of terrorist methods to achieve it, or who would 'knowingly ... [create] ... an environment' that endorses the use of terrorism.[26] Moreover, the concern with non violent ideology as a focus of a counter-terrorism strategy diminishes the prospect of opening up radical but non-violent avenues for democratic political expression as an alternative to the use of terrorism. Writing on the clear distinction between 'disengagement' and 'deradicalisation', Horgan's empirical research found that:

'the disengaged terrorist may not necessarily be ... 'deradicalized' at all ... In fact, in the sample of former terrorists I interviewed from 2006 to 2008, while almost all of the interviewees could be described as disengaged, the vast majority of them could not be said to be 'deradicalized.'[27]

Thus, what in counter-terrorism and security terms could be seen as a success would in deradicalisation (or counter-radicalisation) terms be seen as an abject failure. Yet, in preventing terrorism it is surely the former that we should be concerned with, and one has to question the extent to which any simultaneous focus on non-violent ideology as part of counter-terrorism negatively impacts on the prospects for disengagement, or in preventing terrorism in the first place, if avenues for expressing radical but non-violent views become blocked. Crenshaw, in her research on why terrorism might be abandoned, also found that 'in no case did groups abandon terrorism because they changed their ideological orientation or long-term goals[28]' and, interestingly, that 'Terrorism decreases as the potential for radical collective action increases'.[29]

\section{Democracy and British values}

It is, of course, important to challenge undemocratic ideologies and to promote British values. But, precisely because the United Kingdom is a country steeped in democratic tradition then these dissenting ideologies should be debated and dismissed in the public and political arena and not be tackled as part of a counter-terrorism strategy. Arguably, the existence and promotion of undemocratic doctrines serves the UK with a powerful opportunity to remind its citizens of the virtue of its own values and never to be complacent about them. But this should be part of a broader 


\section{Journal of Terrorism Research}

endeavour to promote democracy within, whoever the domestic adversary - whether they be those advocating communism, fascism, or those that call for undemocratic forms of government based on a form of religious interpretation. Any self-confident democracy should be able to effectively counter those who use their legal and democratic right to voice dissenting ideological views. This self-confidence includes trusting the electorate to endorse British democracy at the polls at the expense of those who would undermine it.

These ideological challenges that are part and parcel of democratic life should not be the concern of counter-terrorism, whether they emanate from a communist party, the British National Party, or from those aiming to establish sharia law in the UK. It is a different matter, of course, if terrorism is used as the method, whatever the ideological cause might be.

\section{On 'vulnerability'}

Finally, and briefly, another persistent theme in the two strategy documents is the extent to which the terrorist threat in the UK is seen as emanating from 'vulnerable' people. In the second version of Contest the words 'vulnerable' and 'vulnerability' (to describe those individuals vulnerable to 'violent extremism') were used no less than 32 times. In the latest Contest strategy this figure fell to 24 but the updated Prevent strategy used the words vulnerable, vulnerability or vulnerabilities in this context a total of 75 times!

The author, in a recent article, has questioned why it is that those who aim to commit terrorist acts are assumed to be vulnerable - 'the idea that they have succumbed to (violent) extremist ideologies and that they need guidance so that they can be rescued from the manipulation of others (online or otherwise), and that they would not carry out such acts of their own volition'.[30] Hence the government's 'intention to provide early support to those who are being drawn into offending' (italics added).[31] In the latest version of Contest the notion of terrorism as somehow being the product of vulnerability or individual fallibility is further embedded through its emphasis on the role of 'Healthcare professionals' who 'may meet and treat people who are vulnerable to radicalisation',[32] while the Prevent strategy argues that:

'there are clearly many opportunities for doctors, nurses and other staff to help protect

people from radicalisation. The key challenge is to ensure that healthcare workers can

identify the signs that someone is vulnerable to radicalisation, interpret those signs correctly and access the relevant support.'[33]

Yet, the 7/7 bombers, for example, could not be said to be vulnerable. [34] Indeed, in May 2006 the Intelligence and Security Committee report into the London terrorist attacks, concluded 'that the threat is as likely to come from those who appear well assimilated into mainstream UK society, with jobs and young families, as from those within socially or economically deprived sections of the community.' [35] This isn't to deny the manipulative influence of online preachers, such as the late Al Awlaki, on would-be recruits, nor to suggest that there haven't been cases of vulnerable people (however defined) who have posed a serious threat, such as that of Nicky Reilly, who had the mental age of a young child and who tried to set off an explosive device in a restaurant in Exeter in May 2008. But, as the author has previously argued,[36] these should not be seen as typical or as evidence of the general vulnerability of those who perpetrate acts of terrorism. The more credible (empirical) research on terrorists suggests that they are in general psychologically no different to the rest of us.[37] Yet, while any notion that terrorists are psychologically deranged or that they have 


\section{Journal of Terrorism Research}

certain personality traits has been discredited, the emphasis on health care professionals 'treating' those vulnerable' to radicalisation or to committing acts of terrorism seems to be leading us towards an adaptation of this thinking.

The impetus towards characterising the terrorist in the UK as largely the outcome of individual fallibility or 'vulnerability' implies a diminished capacity for rational behaviour which also appears to be at variance with conventional wisdom in terrorism studies - that terrorism involves the perpetration of rational and calculated acts of violence. As the author has also previously noted:

'it appears that the possibility that terrorism at home could also be seen as a rational act

by the perpetrators in response to British military action abroad seems to be entirely absent from governmental discourse.[38] In this context one might be forgiven for thinking, therefore, that the use of the term 'vulnerable' has been politically motivated to imply a diminished capacity for rational behaviour - to facilitate the notion that nobody in their right mind could possibly react in such a way to UK interventions in Iraq and Afghanistan, that they must have been manipulated and that those that are being drawn into violent extremism (and are therefore not really acting of their own rational volition) need our help and protection for their 'recuperation' into mainstream society.' [39]

The characterisation of vulnerability, like the focus on non-violent ideology, also has implications for the remit of counter-terrorism because 'it lends itself to a broader spectrum of response concerned with potentially numerous 'vulnerable' individuals'.[40]

\section{Conclusion}

This article has argued that two of the ways that the contemporary terrorist threat has been characterised challenge conventional wisdom on terrorism. Firstly, the idea of combating 'nonviolent' ideology as part of a counter-terrorist strategy deflects us from the predominant academic understanding of terrorism as a method rather than being inherent to any particular doctrine, and especially to any non-violent one; and secondly, that the increasing emphasis on presenting terrorism as the product of vulnerability and personal fallibility, with a concomitantly enhanced role for medical health professionals in response, implies a diminished capacity for rational behaviour when it has generally been agreed within terrorism studies that terrorism entails the perpetration of rational and calculated acts of violence. Policy perspectives are, of course, very different to those of academia and it would be absurd if governments were not to scrutinise both the perpetrators and the cause in whose name terrorism was carried out. But one has to question whether a non-violent ideology itself can be culpable for acts of terrorism. It is surely those who choose to employ the method of terrorism that should be of concern, whatever the doctrine or cause might be. Finally, the international aspiration of achieving a universally agreed definition of terrorism would be further complicated by the notion that certain non-violent ideologies, though non-violent, have some intrinsic connection to terrorism.

About the author: Anthony Richards is a Reader in Terrorism Studies in the School of Law and Social Sciences at the University of East London, where he teaches on the MSc in Terrorism Studies. He is the lead editor for the recently published volume Terrorism and the Olympics: Major 


\section{Journal of Terrorism Research}

event security and lessons for the future (London: Routledge, 2011), and has published on a wide variety of other terrorist related themes including radicalisation, UK counter-terrorism, British public and Muslim attitudes towards terrorism and UK counter-terrorism, homeland security, and terrorism in Northern Ireland. He was previously at the Centre for the Study of Terrorism and Political Violence, University of St Andrews, where he worked on the Economic and Social Research Council project 'The Domestic Management of Terrorist Attacks in the UK', (three of his chapters have been published in the book version of the report: Wilkinson, P. (ed.), Homeland Security in the UK: Future Preparedness for Terrorist Attack Since 9/11, Routledge, June 2007).

\section{Notes:}

[1] UK Counter-Terrorism Strategy (Contest), 2011, p. 6, available at: http://www.homeoffice.gov.uk/publications/counter-terrorism/ counter-terrorism-strategy/ (accessed May 15th 2012).

[2] UK Prevent Strategy, 2011, p. 12, available at: http://www.homeoffice.gov.uk/publications/counter-terrorism/prevent/preventstrategy/ (accessed May 15th 2012).

[3] Ibid. p. 107.

[4] Op. cit. Contest strategy, 2011, p. 12.

[5] Ibid. pp. 61-2.

[6] Op. cit. Prevent strategy, 2011, pp. 1, 5.

[7] Ibid. p. 19.

[8] Ibid. p. 23.

[9] Ibid. p. 24.

[10 Richards, A., 'The problem with 'radicalization', the remit of 'Prevent', and the need to refocus on terrorism in the UK', International Affairs, (January, 2011), p. 143.

[11] 'Pursue, Prevent, Protect, Prepare', The United Kingdom's Strategy for Countering International Terrorism', March 2009, p. 11, available at: http://webarchive.nationalarchives.gov.uk/20100418065544/http://security.homeoffice.gov.uk/news-publications/ publication-search/contest/contest-strategy/contest-strategy-2009?view=Binary (accessed May 16th 2012).

[12] Op. cit Contest, 2011, p. 36.

[13] Op. cit. Prevent, 2011, p. 12.

[14] Bartlett, J., Birdwell, J., King, M., The edge of violence, a radical approach to extremism, Demos, April 16th 2010, available at: http://www.demos.co.uk/files/Edge of Violence_- web.pdf?1271346195, p. 7, (accessed on May 16th 2012). The Demos report describes non-violent radicalisation as 'the process by which individuals come to hold radical views in relation to the status quo but do not undertake, or directly aid or abet terrorist activity' (p. 8).

[15] Leonard Weinberg, Global Terrorism, A Beginner's Guide, Oneworld, p. 2.

[16] Romanov, V., 'The United Nations and the Problem of Combatting International Terrorism', Terrorism and Political Violence', Terrorism and Political Violence, Volume 2, Autumn 1990, No. 3, p. 295.

[17] Acharya, U., 'War on Terror or Terror Wars: The Problem in Defining Terrorism', Denver Journal of International Law and Policy, Volume 37, Issue 4, 2008-2009, p. 656.

[18] Arafat, Y., cited in Hoffman, B., Inside Terrorism, Columbia University Press, 1998, p. 26.

[19] Schmid, A. (1983). Political Terrorism: A Research Guide to Concepts, Theories, Data Bases and Literature. New Brunswick: Transaction, p. 111. 


\section{Journal of Terrorism Research}

[20] Crenshaw, M., Explaining Terrorism, Causes, Processes and Consequences, Routledge, 2011, p. 207.

[21] Pillar, P., 'The Dimensions of Terrorism and Counterterrorism', in Howard, R. And Sawyer, R., (eds.), Terrorism and Counterterrorism, Understanding the New Security Environment, Readings and Interpretations, McGraw-Hill, 2002, p. 28.

[22] Jenkins, B., 'The Study of Terrorism: Definitional Problems', the RAND Corporation, December 1980, pp. 2-3, available at: http://www.rand.org/pubs/papers/2006/P6563.pdf (accessed May 15th 2011).

[23] Op. cit. Demos, p.13

[24] Op. cit. Contest, 2011, pp. 12 and 60.

[25] Ibid. p. 65 .

[26] Ibid. pp. 61-2.

[27] Horgan, J., 'Individual disengagement: a psychological analysis', in Bjorgo, T., and Horgan, J., Leaving Terrorism Behind, Routledge 2009, p. 27.

[28] Crenshaw, M., Explaining Terrorism, Causes, Processes and Consequences, Routledge, 2011, p. 15.

[29] Ibid. p. 195.

[30] Richards, A., 'The problem with 'radicalization', the remit of 'Prevent', and the need to refocus on terrorism in the UK', International Affairs, (January, 2011).

[31] Op. cit. Contest strategy, 2009, p. 89.

[32]Op. cit. Contest strategy, 2011, p. 69.

[33] Op. cit., Prevent strategy, 2011, p. 85 . [34] 'The bombers', BBC News, (undated), available at: http://news.bbc.co.uk/1/shared/ spl/hi/uk/05/london_blasts/investigation/html/bombers.stm (accessed May 15th 2012).

[35] Intelligence and Security Committee, Report into the London Terrorist Attacks on 7th July 2005, May 2006, p. 29 (available at: http://www.cabinetoffice.gov.uk/media/cabinetoffice/corp/assets/publications/reports/intelligence/isc_7july_report.pdf (accessed May 15th 2012).

[36] Op. cit. Richards, pp. 150-1.

[37] See, for example, Crenshaw, M., 'The Causes of Terrorism', Comparative Politics, Vol. 13, No. 4 (July, 1981), p. 390; Horgan, J., The Psychology of Terrorism, Routledge, 2005; Silke, A., 'Becoming a Terrorist', in Silke, A., (ed), Terrorists, Victims and Society, Wiley, 2003;Horgan, J., 'The Search for the Terrorist Personality’, in Silke, A., (ed), Terrorists, Victims and Society, Wiley, 2003.

[38] For example, Prime Minister Blair was reluctant to acknowledge the impact of the Iraq war on the terrorist threat at home while Prime Minister Brown, in his justification for the British presence in Afghanistan as 'protecting British streets', consistently failed to provide a more balanced assessment that would also have acknowledged the use of Afghanistan in Al Qaeda's narrative and therefore its value in terms of propaganda and recruitment.

[39] Op. cit. Richards, p. 151.

[40] Ibid. 